\title{
Survey of Minas frescal cheese from Southwest Minas Gerais for virulence factors and antimicrobial resistance in Escherichia coli isolates
}

\author{
Avaliação em queijos Minas frescal provenientes do Sudoeste de Minas Gerais da presença de \\ fatores de virulência e resistência antimicrobiana em isolados de Escherichia coli
}

\author{
Mõnica Hitomi Okura ${ }^{\mathrm{I}}$ José Moacir Marin'I
}

\section{ABSTRACT}

The soft cheese Minas frescal is one of the most popular cheese in Brazil, which is typically manufactured in small dairy farms under unsatisfactory hygiene conditions. To assess the risk involved in consumption of this cheese, virulence markers were investigated in 330 Escherichia coli strains isolated from 30 Minas frescal cheeses inspected by official government agency (SIF - serviço de inspeção federal), from 50 cheeses not inspected by SIF and 31 cheeses not inspected by SIF with spice added, all of them collected in the southwest of Minas Gerais State. The E. coli isolates were screened for the presence of Shiga toxin-encoding (stx 1 and stx 2), intimin (eae) genes and for the presence of (pap, sfa, afa) genes related to adhesion in epithelial cells. The only gene detected by PCR was the sfa gene at one isolate. The strains were also screened for resistance to 9 antimicrobial drugs. Predominant resistance was to cephalothin, tetracycline and streptomycin. Multidrug resistance was found among isolates from cheese with SIF (16.6\%), cheese without SIF (8.0\%) and cheese without SIF with spice added (30.0\%) what is a reason for concern due to the high consumption of raw milk cheese by the Brazilian population.

Key words: Escherichia coli, cheese, STEC, ExPEC, antimicrobial resistance, Minas frescal.

\section{RESUMO}

O queijo Minas frescal é um dos queijos mais populares no Brasil, ele é tipicamente manufaturado em pequenas fazendas de leite, em condições higienicas insatisfatórias. Para verificar o risco envolvido no consumo deste queijo, marcadores de virulência foram investigados em 330 cepas de isoladas de 30 queijos Minas frescal, inspecionados pela agencia governamental oficial (SIF- serviço de inspeção federal), de 50 queijos não inspecionados pelo SIF e de 31 queijos não inspecionados pelo SIF e com condimentos adicionados. Todos eles foram coletados na região sudeste do Estado de Minas Gerais. As cepas de $\boldsymbol{E}$. coli foram examinadas para a presença de genes codificadores de Shiga toxina (stx1 e stx 2), gene da intimina (eae) e também para a presença dos genes (pap, sfa, afa) relacionados com a adesão em células epiteliais. O único gene detectado por PCR foi sfa em um isolado. As cepas também foram examinadas para a resistência a nove fármacos antimicrobianos. As resistências predominantemente detectadas foram para cefalotina, tetraciclina e estreptomicina. A resistência a múltiplas drogas identificadas entre as cepas de $\boldsymbol{E}$. coli, provenientes de queijo com SIF (16,6\%), queijo sem SIF (8,0\%) e queijo sem SIF com condimentos adicionados (30,0\%), o que representa um motivo de preocupação, devido ao elevado consumo pela população Brasileira de queijos feitos de leite não pasterurizado.

Palavras-chave: Escherichia coli, queijo, STEC, EXPEC, resistência antimicrobiana, Minas frescal.

\section{INTRODUCTION}

Minas frescal cheese is one of the most popular cheeses produced in Brazil, this soft white cheese is made of pasteurized or raw milk. It is characterized by a high $\mathrm{pH}$ and moisture content $(>55 \%)$ and low percentage of salt (1.4-1.6\%) (MORAES et al., 2009). Escherichia coli is used as an indicator of direct or indirect fecal contamination of foods, and therefore the possible presence of enteric pathogens. In cheese, $\boldsymbol{E}$. coli is used as an indicator to assess the contamination and its presence may indicate poor hygiene conditions during processing

IPrograma de Pós-graduacão em Microbiologia Agropecuária, Faculdade de Ciências Agrárias e Veterinárias de Jaboticabal, Universidade Estadual Paulista (UNESP), São Paulo, SP, Brasil.

ID Departamento de Morfologia, Fisiologia e Patologia Básica, Faculdade de Odontologia de Ribeirão Preto (FORP), Universidade de São Paulo (USP), Av. do Café s/n Campus USP, 14040-904, Ribeirão Preto, SP, Brasil. E-mail: jmmarin@forp.usp.br. Autor para correspondência. 
or post-processing contamination (O'BRIEN et al., 2009), in Brazil there are specific rules for the production and commercialization of dairy products (BRASIL, 1996, 2001), however the production and retail sale of no inspected dairy products is common in Brazil (MORAES et al., 2009).

Since the occurrence of an outbreak of foodborne disease caused by enteropathogenic $\boldsymbol{E}$. coli associated with consumption of soft ripened cheese (MARIER et al., 1973), the presence of these microorganisms in cheese acquired additional significance. Verocytotoxin (VT)-producing $\boldsymbol{E}$. coli (VTEC) also known as Shiga toxin-producing $\boldsymbol{E}$. coli (STEC) are among the most important causes of foodborne diseases. They are responsible for overall human gastrointestinal diseases, including watery or blood diarrhea (PATON \& PATON, 1998). The STEC strains can gain access to milk by fecal contamination or by direct excretion (mastitis) from the udder into the milk (LIRA et al., 2004). Outbreaks and sporadic cases of illnesses have been traced to consumption of STEC-contaminated cheese (BAYLIS, 2009).

Some pathotypes of $\boldsymbol{E}$. coli are capable of causing intestinal disease, while others referred to as extraintestinal pathogenic $\boldsymbol{E}$. coli (ExPEC), are responsible for extraintestinal infections. Usually, ExPEC isolates have specialized virulence factors enabling them to colonize host surfaces, injure host tissues, and avoid or subvert host defense systems (JOHNSON et al., 2005). Among them the P fimbriae (encoded by the pap gene), Sfa fimbriae (encoded by sfa genes) and Afa afimbrial (encoded by afa gene) are important virulence factors related to adhesion and usually found among $\boldsymbol{E}$. coli strains causing urinary tract infection (UTI) in humans. Some studies have suggested that food may give raise to human acquired ExPEC strains (JOHNSON et al., 2005; VINCENT et al., 2010).

During the last decade there has been an increasing awareness of potential problems to human health caused by the selection of antimicrobial resistance among food producing animals (AARESTRUP, 2005). Since pathogenic or commensal bacterial species from animals can be transmitted to humans through milk or milk products, it seems prudent to explore not only resistance patterns to antimicrobials used in veterinary medicine, but also to antimicrobials used in human medicine. In Brazil only a limited number of studies concerning the antibiotic resistance of commensal E. coli isolated from cheese have been performed (PANETO et al., 2007).

Cattle are an important reservoir of toxigenic $\boldsymbol{E}$. coli, and have been implicated as a source of $\boldsymbol{E}$. coli that infect and cause disease in human beings (BAYLIS, 2009). The aims of the present study were to determine the presence of STEC and ExPEC strains in Minas frescal cheese and also to verify the resistance of $\boldsymbol{E}$. coli strains isolated from cheese to antimicrobial drugs.

\section{MATERIALS AND METHODS}

Sample collection, microbiological analysis

A hundred-eleven samples of Minas frescal cheese were randomly purchased in the Triangulo Mineiro region in the southwest of Minas Gerais State from supermarkets or small food stores at different cities. Thirty cheese samples have been inspected by official government agencies (SIF-servico de inspecão federal), fifty were not inspected (without SIF) and thirty-one were not inspected and have spice added (Origanum vulgare and/or Pretoselium sativum). All samples were kept under refrigeration in plastic bags; information about dates of production and of assigned shelf lives sometimes were not presented. Cheese samples were collected over a period of 10 months between March and December 2007, and were analyzed on the day of acquisition. Samples were transported under refrigeration $\left(4-6^{\circ} \mathrm{C}\right)$ in thermal boxes containing ice packs and were tested immediately after arrive at the laboratory. A $25 \mathrm{~g}$ portion of each cheese was blended with $225 \mathrm{ml}$ of nutrient broth (Difco, Detroit, USA) for two min at normal speed using a Stomacher lab blender and incubated at $37^{\circ} \mathrm{C}$ for $24 \mathrm{~h}$. An $1 \mathrm{ml}$ sample of the nutrient broth culture was mixed with $9 \mathrm{ml}$ of MacConkey broth (Oxoid, Hampshire, UK) and further incubated at $37^{\circ} \mathrm{C}$ for $24 \mathrm{~h}$. One loop of each tube was streaked on MacConkey agar. At least ten colonies from each plate with typical $\boldsymbol{E}$. coli morphology were selected and examined by biochemical tests, including hydrogen sulphide, citrate, urease and indole (KONEMAN et al., 1997). The technique used to determine the most problable number (MPN) of coliforms was developed according to the AMERICAN HEALTH ASSOCIATION (2001) and U.S. FOOD AND DRUG ADMINISTRATION (2001). Microbiological standards for soft cheese are determined by the official Brazilian parameters of the Ministries of Agriculture and Health (BRASIL 1996, 2001).

\section{Polymerase chain reaction}

Bacterial strains (E. coli isolates) grown overnight in nutrient broth (Sigma Chemical Co, St Louis, USA) at $37^{\circ} \mathrm{C}$ were tested for the presence of $s t x$ (stx 1 and stx 2) and eae genes using the polymerase chain reaction (PCR) protocol of CHINA et al. (1996) 
and the protocol of LE BOUGUENEC et al. (1992) for the presence of pap, sfa, afa genes. DNA templates were prepared by boiling in sterile destilled water. The DNA was subjected to PCR performed in an Eppendorf Mastercycler (Eppendorf AG, Hamburg, Germany). Stx 1, stx 2, eae, pap, sfa and afa genes were detected using primers and PCR conditions in the above-mentioned protocols. The amplified DNA products were separated by electrophoresis on $1.5 \%$ agarose gel, stained with ethidium bromide and detected under ultraviolet light. Reference $\boldsymbol{E}$. coli strains used as controls were EDL 933 (O157:H7, stx1, stx 2, eae), FV L2 (sfa, pap, iuc, hly, cnf-1) and DH5 $\alpha$ (negative control).

\section{Susceptibility testing}

Antimicrobial susceptibility tests were performed using the disk diffusion method recommended by the Clinical and Laboratory Standards Institute (CLSI, 2008). Drug-impregnated disks (CEFAR, São Paulo, BR) were placed on agar surfaces using a disk dispenser. The following nine antimicrobial agents were tested: tetracycline (TET, $30 \mu \mathrm{g}$ ); sulfamethoxazole/trimethoprim (SUT, $25 \mu \mathrm{g}$ );

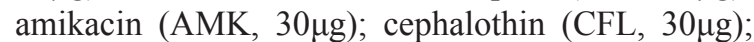
ceftriaxone (CEF, 30 $\mu$ ); gentamicin (GEN, $5 \mu \mathrm{g}$ );

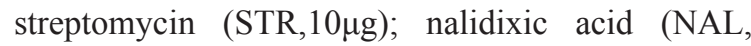
$30 \mu \mathrm{g})$; ciprofloxacin (CIP, $5 \mu \mathrm{g})$.

\section{RESULTS AND DISCUSSION}

A total of one thousand-two hundredforty-three $\boldsymbol{E}$. coli isolates were obtained from cheese samples, 216 isolates from cheese SIF + (with SIF inspection, 30 cheeses), 578 isolates from SIF (without SIF inspection, 50 cheeses) and 449 isolates SIF - / spice (without SIF inspection and added of spice, 31 cheeses). Using Brazilian parameters (BRASIL, 1996, 2001) 10 (30.0\%) cheese samples from SIF +, $35(70.0 \%)$ cheese SIF- and $19(61.0 \%)$ cheese SIF- / spice were in disagreement with all microbiological parameters as the final evaluation
(Table 1). Many authors have been reported the situation of Minas Frescal cheese in Brazil. BRANT et al. (2007) reported $92.5 \%$ of cheese inappropriate for consume, and MORAES et al. (2009) reported 90.9\%. FREITAS et al. (2013) examined 99 Minas frescal cheese samples obtained in retail sale and 44 of those presented $\boldsymbol{E}$. coli counts higher than $5 \times 10^{2}$ colonyforming units $\mathrm{g}^{-1}$. Microbiological contamination of cheese may originate from various sources. Such sources during cheese production might be: starter culture, brine, floor and packaging material, cheese vat, cheese cloth and curd cutting knife, cold room and also must be considered the dairy workers as well (KOUSTA et al., 2010). DIAS et al. (2012) reported on the implementation of good manufacturing practices (GMP) in a small processing unit of cheese in Parana, Brazil that the main hurdles for the implementation of GMP were related to the difficulties to change the hygiene practices of food handlers. Therefore, there is a need for more severe monitoring by the Brazilian Inspection Authorities to improve the sanitation and hygienic practices adopted on farms or small factories.

Randomly three hundred-thirty $\boldsymbol{E}$. coli isolates were choosing to be examined for PCR amplification and antimicrobial resistance. The distribution used was 90 strains from SIF +, 150 strains from SIF-, 90 strains from SIF- / spice. None of the $\boldsymbol{E}$. coli isolates examined by PCR amplification showed the presence of $s t x 1$, stx 2 or eae encoding genes, what means there is no STEC strains among the cheese isolates tested, as shown in table 2. Different cheese varieties have lead evidence of STEC contamination based on presence of stx gene or isolated STEC (BAYLIS, 2009). In France a cluster of four cases of haemolytic uraemic syndrome (HUS) in children, caused by E. coli O157-VT2 was traced to consumption of cheese made with unpasteurized mixed cows' and goats' milk (DESCHÊNES et al., 1996). ALTALHI \& HASSAN (2009) examined 50 samples of raw milk and raw milk products in Saudi Arabia and reported one positive $\boldsymbol{E}$. coli strain carrying $s t x 1$

Table 1 - Distribution of Most Probable Number (MPN) of fecal coliforms at $45^{\circ} \mathrm{C}$ among the Minas frescal cheese from Southwest Minas Gerais.

\begin{tabular}{lccc}
\hline MPN g $^{-1}$ of fecal coliforms & SIF $+*(n=30) * * *$ & SIF- $* *(n=50)$ & SIF- / spice $* * *(n=31)$ \\
\hline $3.0-5.0 \times 10^{1}$ & Samples $(\%)$ & Samples $(\%)$ & Samples $(\%)$ \\
$5.0 \times 10^{1}-5.0 \times 10^{2}$ & $17(57)$ & $8(16)$ & $10(32)$ \\
$5.0 \times 10^{2}-5.0 \times 10^{3}$ & $3(10)$ & $6(12)$ & $9(29)$ \\
\hline
\end{tabular}

* Cheese with SIF inspection; ** cheese without SIF inspection; ***cheese without SIF inspection with spice added; **** number of samples cheese. Anvisa permited limits $=5.0 \times 10^{2} \mathrm{MPN} \mathrm{g}^{-1}$ for Minas frescal cheese; $10^{2}$ for Minas frescal cheese with spices. 
Table 2 - Virulence markers of Escherichia coli isolates from Minas frescal cheese.

\begin{tabular}{|c|c|c|c|}
\hline Virulence markers & $\mathrm{SIF}+*(\mathrm{n}=90) * * * *$ & $\mathrm{SIF}-* *(\mathrm{n}=150)$ & SIF - / spice $* * * \quad(n=90)$ \\
\hline \multicolumn{4}{|l|}{ STEC } \\
\hline stx 1 & $\mathrm{ND} * * * * *$ & ND & ND \\
\hline stx 2 & ND & ND & ND \\
\hline eae & ND & ND & ND \\
\hline \multicolumn{4}{|l|}{ ExPEC } \\
\hline pap & ND & ND & ND \\
\hline sfa & ND & 1 & ND \\
\hline afa & ND & ND & ND \\
\hline
\end{tabular}

$*$ Cheese with SIF inspection; ** cheese without SIF inspection; ***cheese without SIF inspection with spice added; **** number of isolates; $* * * * *$ Not Detected

(3.0\%) gene and two positive strains for stx $2(6.0 \%)$ among the examined samples. ZWEIFEL et al. (2010) in a survey of a 3 year monitoring program in Swiss examined 1,502 cheeses, among them 80 samples of soft cheese and reported the detection of 8 soft cheese $(10 \%)$ contamined by non-O157 STEC strains, all of them carrying the stx 2 gene. GONZALES et al. (2000) examined 44 soft white cheeses (Minas frescal) in Rio de Janeiro, Brazil and isolated 386 E. coli strains none of them with stx genes detected. In Brazil, at the best of our knowledge, only PANETO et al. (2007) reported the analysis of 50 samples of Minas frescal cheese with the recovered of $3 \boldsymbol{E}$. coli isolates carrying the $v t 2$ (stx 2$)$ gene ( 2 isolates) and $v t 1$ (stx 1) gene ( 1 isolate).

In the present work also the adhesions encoding genes pap, sfa and afa were almost absent. Only one isolate (number 301) from cheese SIF- presented the $s f a$ gene $(0.6 \%)$ but it can not be characterized as an ExPEC strain, what means there is no ExPEC strains among the cheese isolates tested. ALTALHI \& HASSAN (2009) in Saudi Arabia did not found pap and sfa genes among the examined raw milk samples but they reported a great percentage of other genes such as trat $\mathrm{T}$ (serum resistance, $51.5 \%$ ), iut A (aerobactin, 33.3\%) and fyu A (yersiniabactin, 24.2\%) among the $\boldsymbol{E}$. coli isolates, all of them considered virulence-associated traits related with ExPEC.

The emergence of antimicrobial resistance among pathogens that impact animal health has been a growing concern in veterinary medicine (VAN DEN BOGAARD \& STOBBERING, 2000). Some E. coli strains which contaminate dairy products represent a direct hazard to human health due to their virulence factors (BAYLIS, 2009), others represent a possible source of genes of transmissible resistance to antimicrobial drugs used for the treatment and prophylaxis of infections diseases in animals (VAN DEN BOGAARD \& STOBBERING, 2000; AARESTRUP, 2005).
The susceptibility to 9 antimicrobial agents for the three hundred-thirty $\boldsymbol{E}$. coli isolates is shown in table 3 . Among the isolates from cheese the highest resistance was observed against cephalothin, streptomycin and tetracycline (Table 3). PANETO et al. (2007) examined $48 \boldsymbol{E}$. coli strains isolated from Minas frescal cheese and they reported resistance to cephalothin $(60.0 \%)$, nalidixic acid (40.0\%), tetracycline (31.0\%), ampicilin (29.0\%) among the isolates examined. However it is necessary to mention that the author above mentioned, combine intermediate sensibility value with the resistance value to create the resistance percentage. Looking in that way the percentage of resistance reported in the present study (Table 3) were quite similar to those above mentioned, but higher than the resistance reported by CAMPOS et al. (2006) for $\boldsymbol{E}$. coli strains isolated from 24 samples of Minas frescal cheese from Goias, Brazil (4.0\% for ampicilin and tetracycline).

UNLU et al. (2011) examined 120 white cheese samples in Turkey and 56 of those (46.6\%) were found to be contaminated with $\boldsymbol{E}$. coli. The authors reported a high level of antimicrobial resistance among the $\boldsymbol{E}$. coli isolates to gentamycin $(60.0 \%)$, tetracycline $(52.0 \%)$ and enrofloxacin $(30.0 \%)$, all of them higher than the percentages of antimicrobial resistance reported in the present study.

E. coli multidrug resistant (MDR) was found in the three types of Minas frescal cheese examined in the present work. The most commonly found MDR were to cephalothin + tetracycline + streptomycin and sulfamethoxazole/trimethoprim + tetracycline + streptomycin. The results were $16.6 \%$ for cheese with SIF inspection, $8.0 \%$ for cheese without SIF inspection and $30.0 \%$ for cheese without SIF inspection with spice added. AMADOR et al. (2009) examined 20 cheese samples in Portugal and isolated 172 bacterial samples, $31.4 \%$ of those displayed a MDR phenotype, a value higher than the 
Table 3 -. Antimicrobial susceptibility of 330 Escherichia coli strains isolated from Minas frescal cheese in Brazil.

\begin{tabular}{|c|c|c|c|c|c|c|}
\hline \multirow{2}{*}{ Antimicrobial drugs } & \multicolumn{2}{|c|}{----SIF +* $(\mathrm{n}=90)^{* * * *}$} & \multicolumn{2}{|c|}{-----SIF - ** $\quad(\mathrm{n}=150)-----$} & \multirow{2}{*}{$\begin{array}{l}--\mathrm{SIF} / \text { spice }^{* * *} \\
\text { I }\end{array}$} & \multirow{2}{*}{$\begin{array}{l}(\mathrm{n}=90)- \\
\mathrm{R}\end{array}$} \\
\hline & $\mathrm{I} * * * * *$ & $\mathrm{R} * * * * * *$ & I & $\mathrm{R}$ & & \\
\hline Cephalothin & $25.6 * * * * * * *$ & 35.5 & 37.3 & 16.0 & 37.8 & 8.9 \\
\hline Ceftriaxone & 5.6 & 11.1 & 8.7 & 0 & 5.6 & 2.2 \\
\hline Gentamicin & 1.1 & 0 & 3.3 & 0 & 2.2 & 4.4 \\
\hline Streptomycin & 5.6 & 20.0 & 26.0 & 7.3 & 40.0 & 20.0 \\
\hline Amikacin & 3.3 & 0 & 12.7 & 4.7 & 22.2 & 10.0 \\
\hline Nalidixic acid & 54.5 & 0 & 49.3 & 13.3 & 42.2 & 15.6 \\
\hline Ciprofloxacin & 0 & 0 & 0 & 0 & 15.6 & 1.1 \\
\hline Tetracycline & 8.9 & 37.8 & 10.0 & 32.7 & 10.0 & 58.9 \\
\hline Sulfamethoxazole/trimethoprim & 8.9 & 7.8 & 2.0 & 6.0 & 0 & 26.7 \\
\hline
\end{tabular}

*Cheese with SIF inspection; ** cheese without SIF inspection; ***cheese without SIF inspection with spice added; **** number of isolates; $* * * * \mathrm{I}=$ intermediate sensibility; $* * * * * * \mathrm{R}=$ resistant; $* * * * * * * 25.6=$ percentage.

results described in the present study. Resistance of E. coli MDR isolated from foods to antimicrobial drugs used in human medicine has been a reason for concern due to the risk of dissemination of these genes among the human microflora.

To conclude, the present study did not find STEC or ExPEC strains among 330 E. coli isolates from Minas frescal cheese. $\boldsymbol{E}$. coli commensal strains isolated from cheeses showed a high level of antimicrobial resistance and multidrug resistance, what it is a reason for concern due to the high consumption of raw milk cheese by the Brazilian population.

\section{ACKNOWLEDGEMENTS}

The authors would like to thank Fundação de Amparo a Pesquisa do Estado de São Paulo (FAPESP) for financial support to the laboratory.

\section{REFERENCES}

AARESTRUP, F.M. Veterinary drug usage and antimicrobial resistance in bacteria of animalorigin. Basic Clinical Pharmacology and Toxicology, v.96, p.271-281, 2005. Available from: $<$ http://onlinelibrary.wiley.com/doi/10.1111/j.1742-7843.2005. pto960401.x/pdf>. Accessed: Set. 18, 2013. doi: 10.1111/j.17427843.2005.pto960401.x.

ALTALHI, A.D.; HASSAN, S.A. Bacterial quality of raw milk investigated by Escherichia coli and isolates analysis for specific virulence-gene markers. Food Control, v.20, p.913-917, 2009. Available from: <http://ac.els-cdn.com/ S0956713509000152/1-s2.0-S0956713509000152-main.pdf? tid $=0945 \mathrm{f} 9 \mathrm{fe}-205911 \mathrm{e} 3 \mathrm{bdb} 600000 \mathrm{aab} 0 \mathrm{f} 26 \& \mathrm{acdnat}=1379505433$ e 73778e326957a318a03c9e93b2cd9e6.DOI: $10.1016 / \bar{j}$. foodcont.2009.01.005>. Accessed: Set. 18, 2013.

AMADOR, P. et al. Resistance to B-lactams in bacteria isolated from different types of Portuguese cheese. International Journal of Molecular Sciences, v.10, p.1538-1551, 2009. Available from:
$<$ http://www.mdpi.com/journal/ijms>. Accessed: Dez. 30, 2013. doi:10.3390/ijms 10041538 .

AMERICAN PUBLIC HEALTH ASSOCIATION (APHA). Compendium of Methods for the Microbiological Examination of foods. $4^{\text {th }}$ Edn, p.676. Washington DC, USA:APHA, 2001.

BAYLIS, C.L. Raw milk and raw milk cheeses as vehicles for infection by Verocytotoxin-producing Escherichia coli. International Journal of Dairy Technology, v.62, p.293-307, 2009. Available from: <http:// onlinelibrary.wiley.com/doi/10.1111/j.14710307.2009.00504.x/pdfD OI:10.1111/j.1471-0307.2009.00504.x>. Accessed:Set. 18, 2013.

BRANT, L.M.F. et al Avaliação da qualidade microbiológica do queijo-de-minas artesanal do Serro-MG. Arquivo Brasileiro de Medicina Veterinária e Zootecnia, v.59, p.1570-1574, 2007. Available from: <http://www.scielo.br/pdf/abmvz/v59n6/33.pdf >. Accessed: Set. 18, 2013.

BRASIL. Ministério da Agricultura. Portaria n 146, from March 07 $7^{\text {th }}$ 1996. Aprova os Regulamentos Técnicos de Identidade e Qualidade dos Produtos Lácteos. Diário Oficial da União, March $11^{\text {th }} 1996$. Available from: <http://extranet.agricultura.gov.br/ sislegis-consulta/consultar $>$. Accessed: Set. 18, 2013.

BRASIL, Ministério da Saúde, Secretaria Nacional de Vigilância Sanitária de Alimentos. Resolução RDC n 12. Aprova o Regulamento Técnico sobre padrões microbiológicos para alimentos. Diário da União, January $10^{\text {th }}, 2001$. Available from: $<$ HTTP://e-legis.anvisa. gov.br/leisref/public>. Accessed: Set. 18, 2013.

CAMPOS, M.R.J.H et al. Caracterização fenotípica pelo antibiograma de cepas de Escherichia coli isoladas de manipuladores, de leite cru e de queijo "Minas Frescal" em um laticínio de Goiás. Ciência Rural, v.36, p.1221-1227, 2006. Disponível: <http://www. scielo.br/pdf/cr/v36n4/a27v36n4.pdf>. Accessed: Set. 18, 2013.

CHINA, B. et al. Typing of bovine attaching and effacing Escherichia coli by multiplex in vitro amplification of virulenceassociated genes. Applied and Environmental Microbiology, v.92, p.3462-3465, 1996. Available from: <http://aem.asm.org/ content/62/9/3462>. Accessed: Set. 18, 2013.

CLSI (CLINICAL AND LABORATORY STANDARDS INSTITUTE). Performance standards for antimicrobial disks 
and dilution susceptibility tests for bacteria isolated from animals. Approved Standard 3.ed. Wayne, PA, 2008.

DESCHENES, G. et al. Cluster of cases of haemolytic uraemic syndrome due to unpasteurized cheese. Pediatric Nephrology, v.10, p.203-205, 1996. Available from: <http://download.springer com/static/pdf/576/art\%253A10.1007\%252FBF00862079.pdf?au th66 $=1379679972 \_23 \mathrm{f} 7 \mathrm{bb} 9 \mathrm{c} 3 \mathrm{a} 874 \mathrm{a} 28 \mathrm{e} 68 \mathrm{fa} 0 \mathrm{~d} 3576 \mathrm{c} 9704 \& \mathrm{ext}=$. pdf>. Accessed: Set. 18, 2013.

DIAS, M.A.C. et al. On the implementation of good manufacturing practices in a small processing unity of mozzarella cheese in Brazil. Food Control, v.24, p.199-205, 2012. Available from: <els-cdn.com/S0956713511003999/1s2.0-S0956713511003999-main.pdf? tid=1db142ee$7163-11$ e3 - abd0-00000aacb35d\&acdnat $=1388415806$ ee2f7912ef4771b0540da9cd5f94cec1>. Accessed: Dez. 30, 2013.

FREITAS, R. et al. Microbiological safety of Minas Frescal Cheese (MFC) and tracking the contamination of Escherichia coli and Staphylococcus aureus in MFC processing. Foodborne Pathogens and Disease, v.10, p.951955, 2013. Available from: <http://online.liebertpub.com/doi/ pdfplus/10.1089/fpd.2013.1525>. Accessed: Dez. 30, 2013.

GONZALES, A.G.M. et al. Enteropathogenicity markers in Escherichia coli strains isolated from soft white cheese and poultry in Rio de Janeiro, Brazil. Food Microbiology, v.17, p.321-328, 2000. Available from: <http://ac.els-cdn.com/ S0740002099903209/1-s2.0-S0740002099903209main.pdf? tid $=399$ af08c-205e11e3b05800000aab0f01\&acdnat $=13795076 \overrightarrow{6}$ $1 \_$e10be8bd101f01fe $>$. Accessed: Set. 18, 2013. doi:10.1006/ fimic.1999.0320.

JOHNSON, J.R. et al. Contamination of retail foods, particularly turkey, from community markets (Minnesota, 1999-2000) with antimicrobial-resistant and extraintestinal pathogenic Escherichia coli. Foodborne Pathogens and Disease, v.2, p. 38-49, 2005. Available from: <http://online.liebertpub.com/doi/ pdfplus/10.1089/fpd.2005.2.38>. Accessed: Set. 18, 2013.

KONEMAN, E.W. et al. Color atlas and textbook of diagnostic microbiology. 5.ed. Philadelphia, Lippincott Company, 1997.

KOUSTA, M. et al. Prevalence and sources of cheese contamination with pathogens at farm and processing levels. Food Control, v.21, p.805-815, 2010. Available from: $<$ http://ac.elscdn.com/S0956713509003235/1-s2.0-S0956713509003235-main. pdf?_tid=7c382d46-7163-11e3-b55c-00000aab0f02\&acdnat $=138$ 8415965_84ba3d1a358>. Accessed: Dez. 30, 2013.

LE BOUGUENEC, C. et al. Rapid and specific detection of the pap, afa and sfa adhesion-encoding operons in uropathogenic Escherichia coli strains by polymerase chain reaction. Journal of Clinical Microbiololy, v.30, p.1189-1193, 1992. Available from: $<$ http://www.ncbi.nlm.nih.gov/pmc/articles/PMC265248/pdf/ jcm00029-0169.pdf>. Accessed: Set. 18, 2013.

LIRA, W.M. et al. The incidence of Shiga toxin-producing Escherichia coli in cattle with mastitis in Brazil. Journal of Applied Microbiology, v.97, p.861-866, 2004. Available from: $<$ http://onlinelibrary.wiley.com/doi/10.1111/j.13652672.200 4.02384.x/pdf $>$. Accessed: Set. 18, 2013. doi:10.1111/j.13652672.2004.02384.X.

MARIER, R. et al. An outbreak of enteropathogenic Escherichia coli foodborne disease traced to imported French cheese. Lancet, v.2, p.1376-1378, 1973. Available from: <http://www. sciencedirect.com/science/article/pii/S0140673673933357\#>. Accessed: Set. 18, 2013.

MORAES, P.M. et al. Foodborne pathogens and microbiological characteristics of raw milk soft cheese produced and on retail sale in Brazil. Foodborne Pathogens and Disease, v.6, p.245-249, 2009. Available from: <http://online.liebertpub.com/doi/pdfplus/10.1089/ fpd.2008.0156>. Accessed: Set. 18, 2013. doi:10.1089=fpd.2008.0156.

O'BRIEN, M. et al. Occurrence of foodborne pathogens in Irish farmhouse cheese. Food Microbiology, v.26, p.910-914, 2009. Available from: $<$ http://www.sciencedirect.com/science/journal/07 400020>. Accessed: Set. 18, 2013.

PANETO, B.R. et al. Occurrence of toxigenic Escherichia coli in raw milk cheese in Brazil. Arquivo Brasileiro de Medicina Veterinária e Zootecnia, v.59, p.508-512, 2007. Available from: $<$ http://www. scielo.br/pdf/abmvz/v59n2/35.pdf >. Accessed: Set. 18, 2013.

PATON, J.C.; PATON A.W. Pathogenesis and diagnosis of Shiga toxin-producing Escherichia coli infection. Clinical Microbiology Reviews, v.11, p.450-479, 1998. Available from: $<$ http://cmr.asm.org/content/11/3/450.full.pdf + html $>$. Accessed: Set. $18,2013$.

UNLU, T. et al. Incidence and antibiotic resistance of Escherichia coli isolated from different kinds of cheese. Journal of Food Safety, v.31, p.54-60, 2011. Available from: <http://onlinelibrary. wiley.com/doi/10.1111/j.17454565.2010.00266.x/pdf>. Accessed: Dez. 30, 2013.

US FOOD AND DRUGS ADMINISTRATION. Center for Food Safety and Applied Nutrition Bacteriological Analytical Manual (on line), 2001. Available: <http://www.cfsm.fda.gov/ebam/bam.toc.html>. Accessed: Aug, 20, 2008.

VAN DEN BOGAARD, A.E.; STOBBERING, E.E. Epidemiology of resistance to antibiotics. Link between animals and humans. International Journal of Antimicrobial Agents, v.14, p.327-335, 2000. Available from: <http://ac.els.cdn.com/ S092485790000145X/1s2.0S092485790000145Xmain.pdf?_tid $=5 \mathrm{af} 68110206311 \mathrm{e} 39 \mathrm{aa} 800000 \mathrm{aab} 0 \mathrm{f0} 1 \mathrm{\& acdnat}=1379509865$ be3812eccb925370c1b983748a783f32>. Accessed: Set. 18, 2013.

VINCENT, C. et al. Food reservoir for Escherichia coli causing urinary tract infections. Emerging Infectious Diseases, v.16, p.88-95, 2010. Available from: <http://wwwnc.cdc.gov/eid/ article/16/1/pdfs/09-1118.pdf>. Accessed: Set. 18, 2013.

ZWEIFEL, C. et al. Characteristics of Shiga toxin-producing Escherichia coli isolated from Swiss raw milk cheese within a 3-year monitoring program. Journal of Food Protection, v.73, p.88-91, 2010. Available from: <http://docserver.ingentaconnect. com/deliver/connect/iafp/0362028x/v73n1/s15.pdf?expires $=1379$ $512164 \&$ id $=75524529 \&$ titleid $=5200021 \&$ accname $=$ UNIVERSID ADE+SAO+PAULO+IF \&checksum=80C14AD022F0655743727 D5B344B34E1>. Accessed: Set. 18, 2013. 